\title{
GABA Receptors on Orexin and Melanin- Concentrating Hormone Neurons Are Differentially Homeostatically Regulated Following Sleep Deprivation $^{1,2,3}$
}

\author{
Hanieh Toossi, Esther del Cid-Pellitero, and ${ }^{\circ}$ Barbara E. Jones
}

DOI:http://dx.doi.org/10.1523/ENEURO.0077-16.2016

Department of Neurology and Neurosurgery, Montreal Neurological Institute, McGill University, Montreal, Quebec, Canada H3A 2B4

\begin{abstract}
Though overlapping in distribution through the hypothalamus, orexin (Orx) and melanin-concentrating hormone $(\mathrm{MCH})$ neurons play opposite roles in the regulation of sleep-wake states. Orx neurons discharge during waking, whereas $\mathrm{MCH}$ neurons discharge during sleep. In the present study, we examined in mice whether $\mathrm{GABA}_{\mathrm{A}}$ and $\mathrm{GABA}_{\mathrm{B}}$ receptors (Rs) are present on Orx and $\mathrm{MCH}$ neurons and might undergo differential changes as a function of their different activities following sleep deprivation (SD) and sleep recovery (SR). Applying quantitative stereological image analysis to dual-immunofluorescent stained sections, we determined that the proportion of Orx neurons positively immunostained for $\mathrm{GABA}_{A}$ Rs was significantly higher following SD ( 48\%) compared with sleep control (SC; $\sim 24 \%)$ and SR ( 27\%), and that the luminance of the $G_{A B A} R_{A}$ s was significantly greater. In contrast, the average proportion of the $\mathrm{MCH}$ neurons immunostained for $\mathrm{GABA}_{\mathrm{A}} \mathrm{Rs}$ was insignificantly lower following SD ( 43\%) compared with SC ( 54\%) and SR $(56 \%)$, and the luminance of the GABA $\mathrm{As}_{A}$ was significantly less. Although, $\mathrm{GABA}_{\mathrm{B}}$ Rs were observed in all Orx and $\mathrm{MCH}$ neurons (100\%), the luminance of these receptors was differentially altered following $S D$. The intensity of $G A B A_{B} R s$ in the Orx neurons was significantly greater after SD than after SC and SR, whereas that in the $\mathrm{MCH}$ neurons was significantly less. The present results indicate that GABA receptors undergo dynamic and differential changes in the wake-active Orx neurons and the sleep-active $\mathrm{MCH}$ neurons as a function of and homeostatic adjustment to their preceding activity and sleepwake state.
\end{abstract}

Key words: $\mathrm{GABA}_{\mathrm{A}} \mathrm{R} ; \mathrm{GABA}_{\mathrm{B}} \mathrm{R}$; homeostasis; mice; waking

\section{Significance Statement}

The activity of single neurons is regulated in a homeostatic manner such that prolonged activity results in decreased excitability. Orexin neurons discharge during waking, whereas $\mathrm{MCH}$ neurons do so during sleep. Here, we examined whether the inhibitory GABA receptors (Rs) on Orexin and $\mathrm{MCH}$ neurons would change differentially as a function of their different activities following sleep deprivation and sleep recovery. Whereas $\mathrm{GABA}_{\mathrm{A}} R$ and $\mathrm{GABA} \mathrm{B}_{\mathrm{B}} \mathrm{R}$ immunostaining appeared to increase on Orexin neurons, it appeared to decrease on $\mathrm{MCH}$ neurons after sleep deprivation relative to sleep control and sleep recovery. GABA receptors thus undergo differential changes on Orx and $\mathrm{MCH}$ neurons as a function of and homeostatic adaptation to their different activities during waking and sleep. 


\section{Introduction}

Orexin (Orx) and melanin-concentrating hormone $(\mathrm{MCH})$ peptides are contained in distinct though codistributed neurons in the hypothalamus (Bittencourt et al., 1992; Broberger et al., 1998; de Lecea et al., 1998). From multiple lines of evidence, they appear to play opposite roles in the regulation of waking and sleep. Pre-pro-Orx knock-out mice present with a syndrome of narcolepsy with cataplexy, marked by the sudden passage from waking to REM sleep with muscle atonia (Chemelli et al., 1999). Humans having narcolepsy with cataplexy have a reduced number of Orx neurons or an absence of its peptide in CSF (Peyron et al., 2000; Thannickal et al., 2000). In rats, Orx neurons fire maximally during waking and become virtually silent during sleep (Lee et al., 2005), and they express c-Fos, a marker for neuronal activity, following sleep deprivation (SD) and not sleep recovery (SR; Modirrousta et al., 2005). In contrast, $\mathrm{MCH}$ neurons do not fire during waking, but fire sparsely during slowwave sleep (SWS) and maximally during REM or paradoxical sleep (PS) (Hassani et al., 2009), and they do not express c-Fos after SD but do so after SR (Verret et al., 2003; Modirrousta et al., 2005). We queried whether the different discharge profiles of the Orx and $\mathrm{MCH}$ neurons would be associated with different homeostatic responses of those neurons to SD.

Neuronal activity is regulated in a homeostatic manner such that increases in activity are compensated for by decreases in excitability and decreases in activity by increases in excitability (Turrigiano, 1999). These changes are mediated in part by changes in receptors to the inhibitory neurotransmitter GABA, as well as by reciprocal changes in those to the excitatory neurotransmitter, glutamate (Turrigiano et al., 1998; Kilman et al., 2002; Marty et al., 2004). With the knowledge that Orx neurons are active, whereas $\mathrm{MCH}$ neurons are silent during continuous waking with SD, we thus examined whether the changes in activity that occur in those neurons would be associated with differential changes in the receptors to GABA. Through in vitro studies, it is known that Orx neurons are hyperpolarized and inhibited by both $\mathrm{GABA}_{\mathrm{A}}$ (eg, muscimol) and $\mathrm{GABA}_{\mathrm{B}}$ (eg, baclofen) receptor agonists and that $\mathrm{MCH}$ neurons are inhibited by $\mathrm{GABA}_{\mathrm{A}} \mathrm{R}$ agonists (Eggermann et al., 2003; van den Pol et al., 2004;

Received April 7, 2016; accepted May 27, 2016; First published June 01, 2016.

${ }^{1}$ The authors report no conflict of interest.

${ }^{2}$ Author contributions: H.T., E.d.C.-P., and B.E.J. planned the study; H. T. and E.d.C.-P. performed behavioral experiments; H.T. processed and analyzed the immunohistochemical material; H.T. and B.E.J. wrote the paper.

${ }^{3}$ This work was supported by grants from the Canadian Institutes of Health Research (CIHR, MOP-82762 and MOP-130502) to B.E.J. We thank Lynda Mainville for technical assistance, Anton Plavski for contribution to behavioral experiments, and Thomas Stroh for imaging consultation.

Correspondence should be addressed to Barbara E. Jones, Montreal Neurological Institute, 3801 University Street, Montreal, QC, Canada H3A 2B4. E-mail: barbara.jones@mcgill.ca.

DOI:http://dx.doi.org/10.1523/ENEURO.0077-16.2016

Copyright (C) 2016 Toossi et al.

This is an open-access article distributed under the terms of the Creative Commons Attribution 4.0 International, which permits unrestricted use, distribution and reproduction in any medium provided that the original work is properly attributed.
Xie et al., 2006). We thus investigated whether homeostatic changes in response to state specific prolonged activity or absence thereof would be evident in $\mathrm{GABA}_{A} R$ and $G A B A_{B} R$ immunostaining following $S D$ and $S R$ in the Orx and $\mathrm{MCH}$ neurons.

\section{Materials and Methods}

All procedures were done in accordance with the $\mathrm{Ca}$ nadian Council on Animal Care and were approved by the McGill University Animal Care Committee.

\section{Animals}

Male adult mice ( $n=25$; C57BL/6, 20-25g) were received from the supplier (Charles River Laboratories) and housed individually in cages, which were maintained at an ambient temperature of $22^{\circ} \mathrm{C}$, in a $12 \mathrm{~h}$ light/dark cycle (lights on from 7:00 A.M. to 7:00 P.M.) and they were given ad libitum access to water and food. Animals were maintained in their home cages for the duration of the experiment and therein recorded by video alone (VM; $n=13$ ) or by video plus telemetry (VTM; $n=12)$. For telemetric recording of the electroencephalogram (EEG), a transmitter (F20-EET, Data Sciences International) was implanted subcutaneously along the flank and connected to two EEG electrodes placed symmetrically over parietal cortex and two reference electrodes placed over the cerebellum. Following surgery, the mice were allowed 1 week to recover.

\section{Sleep deprivation and recovery experimental procedures}

As employed in another study (del Cid-Pellitero, Plavski, Mainville and Jones, unpublished observations), four experimental groups of mice were processed: (1) sleep control (SC), having undisturbed sleep and waking for $2 \mathrm{~h}$ from $\sim 2: 00$ to $\sim 4: 00$ P.M. ( ZZT 7-9; $n=7$ ); (2) SD, being submitted to $2 \mathrm{~h}$ of SD from $\sim 2: 00$ to $\sim 4: 00$ P.M. ( $\sim$ ZT 7-9; $n=6$ ); (3) SD, being submitted to $4 \mathrm{~h}$ of SD from $\sim 12: 00$ to $\sim 4: 00$ P.M. ( ZT 5-9; $n=5$ ); and (4) SR, being subjected to $4 \mathrm{~h}$ of SD from $\sim 10: 00$ A.M. to $\sim 2: 00$ P.M. followed by $2 \mathrm{~h}$ SR from $\sim 2: 00$ to $\sim 4: 00$ P.M. ( $\sim$ ZT $7-9 ; n=7)$. SD was performed by preventing mice from going to sleep by stimulation of the whiskers with a soft paintbrush. For scoring of sleep and waking, mice were recorded by VM for behavior $(n=13)$ or by VTM for behavior with EEG $(n=12)$ using HomeCageScan software (3.0; Clever Systems). At the end of the experimental period $\sim$ 4:00 P.M. ( ZT 9), the mice were immediately anesthetized with sodium pentobarbital (Euthanyl, 100 $\mathrm{mg} / \mathrm{kg}$; Bimeda-MTC Pharmaceutical). Brains were fixed by transcardial perfusion with $30 \mathrm{ml}$ saline followed by $200 \mathrm{ml}$ of $3 \%$ paraformaldehyde. The brains were removed and placed for $1 \mathrm{~h}$ in $3 \%$ paraformaldehyde for postfixation at $4^{\circ} \mathrm{C}$, transferred to $30 \%$ sucrose solution for cryoprotection at $4^{\circ} \mathrm{C}$ for $2 \mathrm{~d}$, and then frozen and stored at $-80^{\circ} \mathrm{C}$.

\section{Immunohistochemical processing}

Brains were cut and processed in batches of two to four, which included mice from SC, SD, and/or SR groups of the same experimental session or period. Coronal sec- 
tions were cut on a freezing microtome at $20 \mu \mathrm{m}$ thickness through the diencephalon. Adjacent series of sections were collected at $200 \mu \mathrm{m}$ intervals for immunohistochemical staining. Free-floating sections were rinsed in $0.1 \mathrm{M}$ trizma saline buffer, $\mathrm{pH} 7.4$, and then incubated in $6 \%$ normal donkey serum buffer for $30 \mathrm{~min}$ and subsequently incubated overnight at room temperature in a buffer containing $1 \%$ normal donkey serum with combinations of two primary antibodies: goat anti-MCH (1:250; Santa Cruz Biotechnology, Catalog \#sc-14507, RRID: $A B$ 2166711) or goat anti-Orx (1:500; Santa Cruz Biotechnology, Catalog \#sc-8070, RRID: AB_653610) with mouse anti-GABA ${ }_{A} R$-chain [1:100; clone BD17, Millipore (Chemicon), Catalog \#MAB 341, RRID: AB_2109419] or guinea pig anti-GABA ${ }_{B} R 1$ [1:2500; Millipore (Chemicon), Catalog \#AB1531, RRID: AB_2314472]. Both the $\mathrm{GABA}_{A} \mathrm{R} \beta$-chain and $\mathrm{GABA}_{B} \mathrm{R} 1$ antibodies were produced and characterized years ago and have since been in use over many years (Fritschy and Mohler, 1995; Wan et al., 1997; Nusser et al., 1998; Bonino et al., 1999; Margeta-Mitrovic et al., 1999; Filippov et al., 2000; Straessle et al., 2003). Subsequently, sections were incubated at room temperature for $2 \mathrm{~h}$ in appropriate combinations of cyanine-conjugated (Cy3 or Cy5) secondary antibodies from donkey (Jackson ImmunoResearch Laboratories): Cy5-conjugated anti-goat (1:800; Catalog \#705-175-147, RRID: AB_2340415) with Cy3-conjugated anti-mouse (1: 1000; Catalog \#715-165-150, RRID: AB_2340813), or Cy3-conjugated anti-guinea pig (1:1000; Catalog \#706165-148, RRID: AB_2340460). After rinsing the sections with trizma saline, sections were stained with green fluorescent Nissl stain (FNS; 1:2000; Molecular Probes, Catalog \#N-21480) for 20 min. Finally, sections were rinsed, mounted, and coverslipped with glycerol.

\section{Image analysis}

Triple-stained sections were viewed with a Leica DMLB microscope equipped with fluorescence filters for excitation and emission of Cy2, Сy3, and Cy5 dyes, a digital camera (Orca-R ${ }^{2}$, C10600-10B, Hamamatsu Photonics $\mathrm{KK})$ and an $x-y-z$ movement-sensitive stage. Images were acquired from three sections in each series (with $200 \mu \mathrm{m}$ intervals between sections) through the Orx and $\mathrm{MCH}$ neurons in the tuberal hypothalamus using Stereolnvestigator software (MicroBrightField). With the optical fractionator probe for unbiased sampling and counting, contours were first traced with a $5 \times$ objective around all the Orx or $\mathrm{MCH}$ neurons in each section within the lateral hypothalamus, perifornical area, dorsomedial nucleus, and/or zona incerta (Modirrousta et al., 2005). For sampling, a grid size of $250 \times 150 \mu \mathrm{m}^{2}$ was used over each contour, and for cell counting and measurements, a counting frame of $120 \times 120 \mu \mathrm{m}^{2}$ was used and placed within each rectangular space by the program. In these, multichannel image stacks were acquired under a $40 x$ objective and were comprised by optical sections of 0.5 $\mu \mathrm{m}$ thickness through the mounted histological section of $\sim 15 \mu \mathrm{m}$ thickness. Within these images, the tops of all cells located $<1 \mu \mathrm{m}$ from the surface of the section were counted, thus through $14 \mu \mathrm{m}$ of the section within the counting frame. Across the three sections, $\sim 38$ counting frames for Orx neurons and 59 for $\mathrm{MCH}$ neurons were acquired and analyzed per series. With this sampling, the average number of Orx + cells counted across series on one side was $56.6 \pm 0.70$ (mean \pm SEM), corresponding to an estimated total number of $1559 \pm 70$ Orx + neurons within one side of the tuberal hypothalamus of the mouse. The average number of $\mathrm{MCH}$ cells counted was $83.96 \pm$ 0.80 , corresponding to an estimated total number of 2364 $\pm 86 \mathrm{MCH}+$ neurons. By moving through the $z$-plane, the double-labeling of the cells for the $\mathrm{GABA}_{\mathrm{A}}$ receptors (Rs) on the membrane or $\mathrm{GABA}_{B} \mathrm{Rs}$ in the cytoplasm was determined. Estimated total numbers of double-labeled cells were computed for each series $\left(G A B A_{A} R-O r x\right.$ or $\mathrm{GABA}_{A} \mathrm{R}-\mathrm{MCH}$ in 12 VTM and GABA ${ }_{B}$ R-Orx or GABA ${ }_{B}$ R$\mathrm{MCH}$ in $13 \mathrm{VM}$ ) and expressed as percentage of Orx + or $\mathrm{MCH}+$ cell populations per series.

Luminance measurements were performed on the Orx + and $\mathrm{MCH}+$ cells that had been counted as positively stained for $G_{A B A} R$ or $G A B A_{B} R$ in the images randomly acquired and counted using Optical Fractionator (above). So as to analyze similar numbers across groups, 8-10 double-labeled Orx + or $\mathrm{MCH}+$ cells, which were present in all animals, were analyzed per animal. The images had been acquired under the same gain and exposure for each series using an 8 bit setting of the digital camera to yield arbitrary units between 0 and 256 in the converted grayscale of the fluorescent images. To measure the luminance of the receptors, different approaches were used for the $\mathrm{GABA}_{\mathrm{A}}$ Rs concentrated over the plasma membrane versus the $\mathrm{GABA}_{B}$ Rs located in the cytoplasm as well as over the membrane. For membrane $\mathrm{GABA}_{\mathrm{A}} \mathrm{Rs}$, a box of $1.5 \times 0.3 \mu \mathrm{m}^{2}$ was placed over the membrane and another over the nucleus to measure and subtract background staining in each cell. For membrane plus cytoplasmic $\mathrm{GABA}_{\mathrm{B}} \mathrm{Rs}$, a donut-shaped contour was drawn around the cytoplasm and plasma membrane, and another traced around the nucleus to measure and subtract background staining in each cell.

Cell counts and luminance measurements were analyzed between experimental groups for each cell type (Orx or $\mathrm{MCH})$ and receptor $\left(\mathrm{GABA}_{\mathrm{A}}\right.$ or $\left.\mathrm{GABA}_{\mathrm{B}}\right)$ using one-way ANOVA for main effect of group followed by post hoc paired-comparisons with Tukey's HSD correction for differences between groups (SYSTAT Software, v13; Table 1). Given that there was no significant difference between the two SD $2 \mathrm{~h}$ and $4 \mathrm{~h}$ groups, they were combined into one SD group.

Sections were also viewed and images acquired for this publication with an LSM 710 confocal laser-scanning microscope equipped with $\mathrm{Ar} 488 \mathrm{~nm}, \mathrm{He}-\mathrm{Ne} 543 \mathrm{~nm}$, and $\mathrm{He}-\mathrm{Ne} 633 \mathrm{~nm}$ lasers for excitation and emission of Cy2, Cy3, and Cy5 dyes. Image stacks were acquired under $63 \times$ oil objective (1.4 numerical aperture, $0.5 \mu \mathrm{m}$ thickness for each optical section) with a 1.0 airy unit pinhole size for each channel. All figures were prepared and composed in a consistent manner for brightness and contrast across groups using Adobe Creative Suite (vCS4). 
Table 1. Summary of statistics

\begin{tabular}{|c|c|c|c|c|c|c|c|}
\hline \multirow{2}{*}{ Dataset } & \multirow{2}{*}{ Figure } & \multirow{2}{*}{$\begin{array}{l}\text { One-way ANOVA } \\
\text { (group }=3 \text { levels) } \\
F \text { value }\end{array}$} & \multirow{2}{*}{$\begin{array}{l}\text { df; } \\
\text { group, error }\end{array}$} & \multirow{2}{*}{$p$ value } & \multicolumn{3}{|c|}{$\begin{array}{l}\text { Tukey's HSD paired-comparisons } \\
p \text { value }\end{array}$} \\
\hline & & & & & SC-SD & SC-SR & SD-SR \\
\hline$\%$ Wake & $1 \mathrm{~A}$ & 1032.33 & 2,22 & $<0.001$ & $<0.001 *$ & $<0.001 \S$ & $<0.001 *$ \\
\hline$\% \mathrm{GABA}_{\mathrm{A}} \mathrm{R}+/ \mathrm{Orx}+$ & 1B1 & 10.27 & 2,9 & 0.005 & $0.009 *$ & 0.910 & $0.010 *$ \\
\hline$\% \mathrm{GABA}_{\mathrm{A}} \mathrm{R}+/ \mathrm{MCH}+$ & 1B2 & 1.48 & 2,9 & 0.270 & $\mathrm{n} / \mathrm{a}$ & $\mathrm{n} / \mathrm{a}$ & $\mathrm{n} / \mathrm{a}$ \\
\hline Lum GABA ${ }_{A} R: O r x+$ & $1 \mathrm{C} 1$ & 7.43 & 2,115 & 0.001 & $0.010 *$ & 0.800 & $0.002 *$ \\
\hline Lum GABA $A_{A}$ R:MCH+ & $1 \mathrm{C} 2$ & 5.88 & 2,117 & 0.004 & $0.010 *$ & 0.970 & $0.020 *$ \\
\hline$\% \mathrm{GABA}_{\mathrm{B}} \mathrm{R}+/ \mathrm{Orx}+$ & 1D1 & $\mathrm{n} / \mathrm{a}$ & $\mathrm{n} / \mathrm{a}$ & $\mathrm{n} / \mathrm{a}$ & $\mathrm{n} / \mathrm{a}$ & $\mathrm{n} / \mathrm{a}$ & $\mathrm{n} / \mathrm{a}$ \\
\hline$\% \mathrm{GABA}_{\mathrm{B}} \mathrm{R}+/ \mathrm{MCH}+$ & 1D2 & $\mathrm{n} / \mathrm{a}$ & $\mathrm{n} / \mathrm{a}$ & $\mathrm{n} / \mathrm{a}$ & $\mathrm{n} / \mathrm{a}$ & $\mathrm{n} / \mathrm{a}$ & $\mathrm{n} / \mathrm{a}$ \\
\hline Lum GABA ${ }_{B}$ R:Orx + & $1 \mathrm{E} 1$ & 15.93 & 2,127 & $<0.001$ & $<0.001 *$ & 0.970 & $<0.001 *$ \\
\hline Lum GABA ${ }_{B} R: M C H+$ & 1E2 & 27.16 & 2,127 & $<0.001$ & $<0.001 *$ & 0.860 & $<0.001 *$ \\
\hline
\end{tabular}

\section{Results}

\section{Sleep-wake states across groups}

Mice were prevented from falling asleep in the SD group ( $n=11$ ) and were thus continuously awake, whereas those in the SC group $(n=7)$ and SR group $(n=$ 7) were awake for only a small percentage of the time during the $2 \mathrm{~h}$ prior to termination at $\sim 4: 00$ P.M. (Fig. 1A; Table 1). After having been previously sleep deprived, mice in the SR group were awake less or reciprocally asleep significantly more of the time (92.61 $\pm 2.21 \%$, mean \pm SEM) than the SC mice $(76.77 \pm 2.56 \%)$, indicating a homeostatic response to SD. Mice in SC and SR groups spent the majority of time in NREM sleep (66.93 \pm $1.71 \%, n=3$ and $82.29 \pm 4.07 \%, n=3$, respectively) and minimal time in REM sleep (9.28 $\pm 0.89 \%, n=3$ and $12.03 \pm 0.87 \%, n=3$, respectively). Both NREM and REM sleep were significantly increased during SR relative to SC (del Cid-Pellitero, Plavski, Mainville and Jones, Unpublished observations).

GABA $_{A}$ Rs on Orx and $M C H$ neurons after SD and SR Triple-stained sections for $\mathrm{GABA}_{A} \mathrm{R} / \mathrm{FNS}$ with either Orx or $\mathrm{MCH}$ were analyzed to assess the presence and intensity of $\mathrm{GABA}_{A} \mathrm{Rs}$ on Orx and $\mathrm{MCH}$ neurons across the three groups (SC, $S D$, and $S R$ ). $\mathrm{GABA}_{A} R$ immunostaining appeared to be located on the plasma membrane of the Orx and $\mathrm{MCH}$ neurons, as well as that of other surrounding neurons (Figs. 2, 3).

$\mathrm{GABA}_{A} R$ immunostaining was minimal and patch-like on the plasma membrane of the Orx-positive $(+)$ neurons, whereas it was often moderate and continuous on the membrane of surrounding Orx-negative neurons in the same sections (Fig. 2). Though minimal on the Orx + neurons, the $G A B A_{A} R$ immunostaining appeared to be more intense after SD compared to that after SC or SR (Fig. 2A-C). The average proportion of the Orx + neurons, which appeared positively immunostained (+) for $\mathrm{GABA}_{A} \mathrm{Rs}$ on the membrane was significantly greater in the SD group ( $48.45 \pm 4.09 \%, n=6$ mice) compared to that in the SC and SR groups $(23.93 \pm 3.74 \%, n=3$ and $26.93 \pm 4.37 \%, n=3$, respectively; Fig. 1B1; Table 1). The average luminance of the $\mathrm{GABA}_{A} R$ immunostaining on the Orx + neurons was also significantly higher in SD (58.71 $\pm 2.90, n=60$ cells) than in SC and SR groups (46.4 $\pm 3.42, n=30$ and $43.17 \pm 2.56, n=28$, respec- tively; Fig. 1C1; Table 1). The luminance measures did not differ between SC and SR, indicating that the $\mathrm{GABA}_{A} R$ returned to control or baseline levels during $S R$.

$\mathrm{GABA}_{\mathrm{A}} \mathrm{R}$ immunostaining appeared to be relatively continuous around the plasma membrane of the $\mathrm{MCH}+$ neurons and somewhat more intense compared to that on Orx + neurons (Fig. 3). Moreover, the $\mathrm{GABA}_{A} \mathrm{R}$ immunostaining on the $\mathrm{MCH}+$ neurons appeared to be moderate in the SC and SR groups (Fig. $3 A-C$ ). In contrast, it appeared minimal following $S D$, even though it was prominent on surrounding $\mathrm{MCH}$-negative neurons (Fig. 3B). The average proportion of $\mathrm{MCH}+$ neurons that appeared $\mathrm{GABA}_{A} \mathrm{R}+$ decreased, though not significantly so, following SD (42.86 $\pm 6.40 \%, n=6$ mice) compared with SC and SR $(54.38 \pm 3.74 \%, n=3$ and $55.7 \pm 2.55 \%, n=3$ respectively; Fig. 1B2; Table 1). The average luminance of the $\mathrm{GABA}_{A} \mathrm{R}$ on the $\mathrm{MCH}+$ neurons decreased significantly after SD $(34.43 \pm 2.45, n=60$ cells) compared SC and SR (45.95 $\pm 3.31, n=30$ and $44.95 \pm 2.59, n=30$, respectively; Fig. 1C2; Table 1). The measures did not differ between SC and SR, indicating that the $\mathrm{GABA}_{A} R$ returned to control or baseline levels during SR.

GABA $_{B}$ Rs on Orx and $\mathrm{MCH}$ neurons after SD and SR Triple-staining for $\mathrm{GABA}_{\mathrm{B}} \mathrm{R} / \mathrm{FNS}$ and either Orx or $\mathrm{MCH}$ was performed to examine the incidence of $G A B A_{B} R s$ on Orx or $\mathrm{MCH}$ neurons across the three groups (SC, SD, and $S R$ ). $G A B A_{B} R$ immunostaining appeared to be predominantly located over the cytoplasm of the cells, whereas only minimally located on the membrane of both the Orx and $\mathrm{MCH}$ neurons (Figs. 4, 5).

In the Orx + neurons, $\mathrm{GABA}_{\mathrm{B}} \mathrm{R}$ immunostaining was prominent in the soma and proximal dendrites and appeared to be more dense and intense after SD than after SC and SR (Fig. 4A-C). Nonetheless, all Orx+ neurons (100\%) were judged to be positively immunostained for the $\mathrm{GABA}_{\mathrm{B}} \mathrm{R}$ in all mice of all groups $(n=4$ in SC and SR groups, $n=5$ in SD group; Fig. 1D1; Table 1). On the other hand, the luminance of the $G_{A B A} R$ in the Orx neurons was significantly higher following $\mathrm{SD}(22.84 \pm 1.35, n=$ 50 cells) compared with SC and SR $(14.36 \pm 1.21, n=40$ and 14.76 \pm 1.03, $n=40$, respectively; Fig. 1E1; Table 1). The luminance did not differ between SC and SR, indicating that the $G A B A_{B} R$ returned to control or baseline levels during SR. 

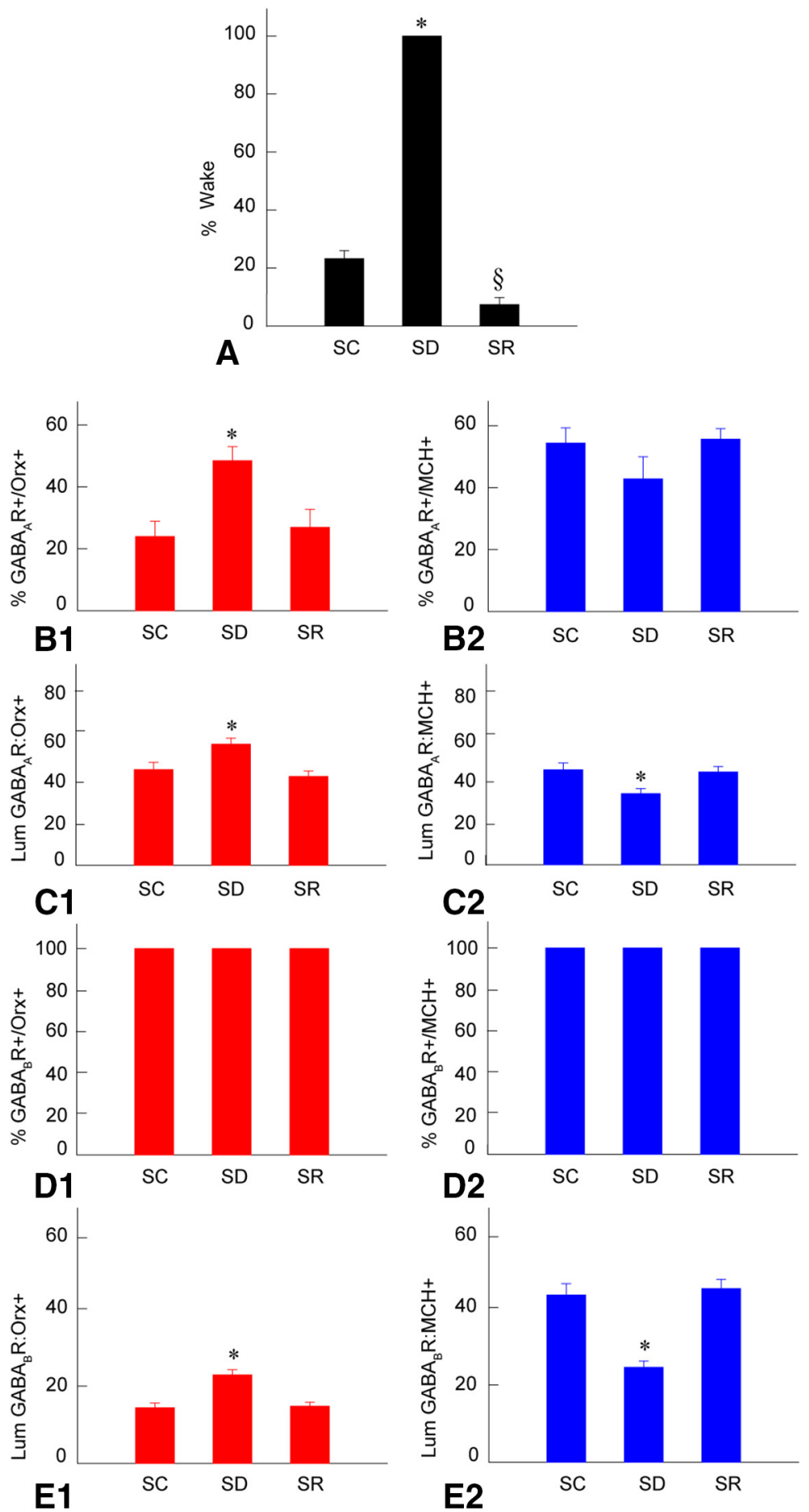

Figure 1. Sleep-wake states and GABA receptors in Orx and $\mathrm{MCH}$ neurons across groups. $\boldsymbol{A}$, Percentage of time spent in wake during the $2 \mathrm{~h}$ preceding termination in SC, SD, and SR groups. Percentage wake is significantly higher in SD compared to SC and $\mathrm{SR}$ and significantly lower in SR compared to SC. $\boldsymbol{B}$, Proportion of Orx + or MCH+ neurons bearing GABA $\mathrm{R}_{A}$ across groups. The percentage Orx $+/ G A B A_{A} R+$ was significantly greater in SD compared to $S C$ and $S R(B 1)$, whereas the percentage $M C H+/ G A B A_{A} R+$ neurons was insignificantly less in SD compared to SC and SR (B2). $\boldsymbol{C}$, Luminance of the GABA $\mathrm{A}_{\mathrm{A}}$ immunofluorescence on Orx and $\mathrm{MCH}$ neurons across groups, which was significantly increased on the Orx + neurons $(\mathbf{C} 1)$ and decreased on the $\mathrm{MCH}+\mathrm{neurons}(\mathbf{C 2})$ in SD compared to SC and SR. $\boldsymbol{D}$, Proportion of the Orx (D1) and $\mathrm{MCH}(\boldsymbol{D} 2)$ neurons expressing $\mathrm{GABA}_{\mathrm{B}} \mathrm{Rs}$, which did not change across groups. $\boldsymbol{E}$, Luminance of the $\mathrm{GABA}_{\mathrm{B}} \mathrm{R}$ which was significantly higher in Orx+ neurons (E1), and significantly lower in $\mathrm{MCH}+$ neurons (E2) following SD compared to SC and SR. Note that the changes in GABARs on Orx neurons parallel the percentage wake, whereas those on $\mathrm{MCH}+$ neurons parallel the percentage sleep across groups. *Indicates significant difference of SD relative to SC and SR $(p<0.05)$. \$lndicates significant difference of SR relative to SC $(p<0.05)$, according to post hoc paired comparisons following one-way ANOVA (Table 1). Abbreviations: Lum, luminance. 


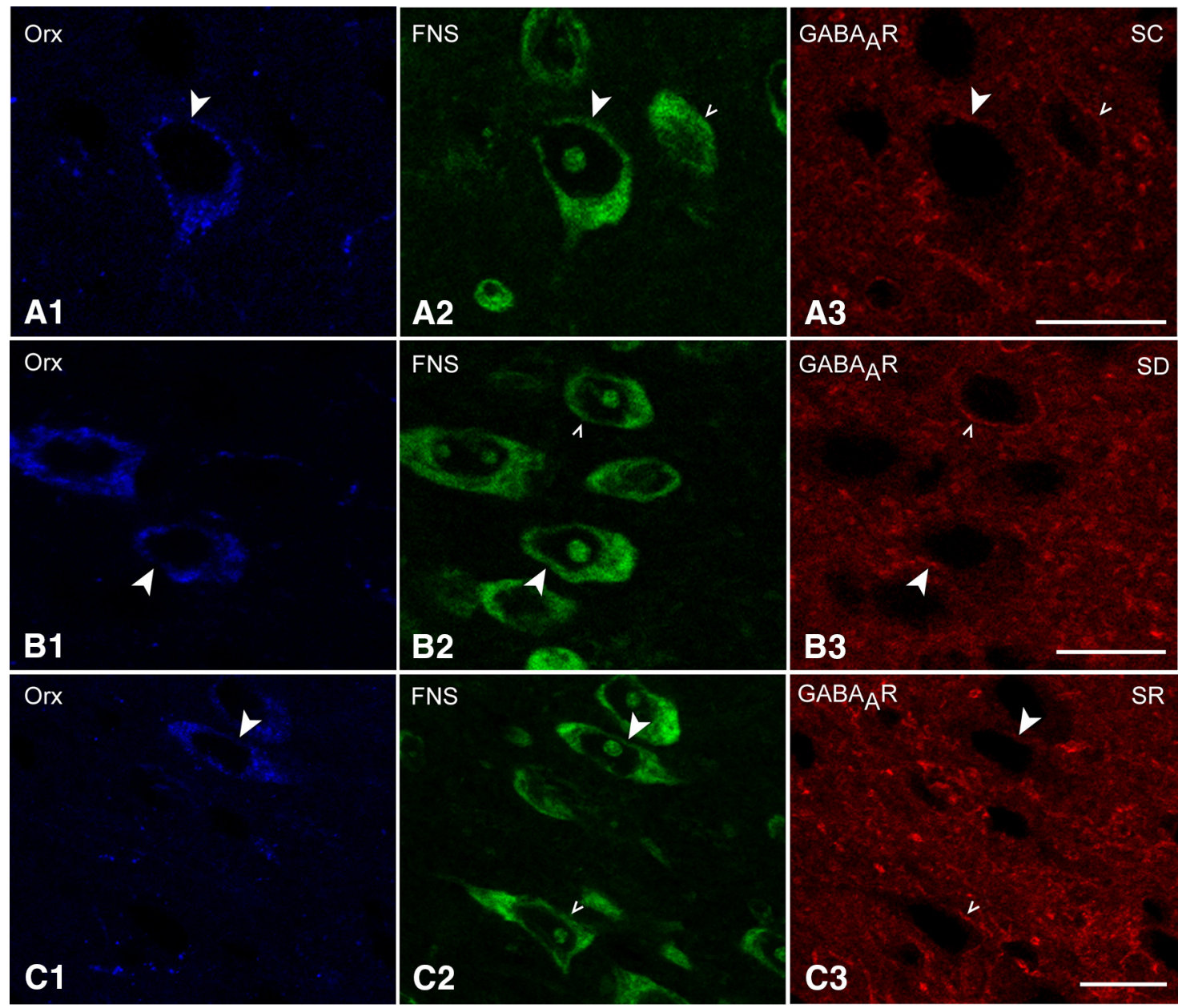

Figure 2. $G A B A_{A} R s$ in Orx neurons across groups. Confocal images of immunostained sections indicate that the $G A B A_{A} R$ (red) was minimal on Orx + neurons (blue, indicated by filled arrowheads) compared to that on adjacent Orx-negative neurons (stained with FNS, green, indicated by carets). $\boldsymbol{A}$, The $\mathrm{GABA}_{\mathrm{A}} \mathrm{R}$ immunofluorescence was minimally visible as small clusters along a portion of the plasma membrane of an Orx + cell body in an SC mouse, in which it was readily visible along the full membrane of an Orx-negative cell body. $\boldsymbol{B}$, The GABA $\mathrm{A}_{\mathrm{A}} \mathrm{R}$ staining was more visible as larger clusters along a larger portion of the membrane of an Orx + cell in an SD mouse. $\boldsymbol{C}$, The $\mathrm{GABA}_{\mathrm{A}} \mathrm{R}$ staining was similar in an SR mouse to that in SC. Scale bars, $10 \mu \mathrm{m}$. Image thickness: $\boldsymbol{A}, \boldsymbol{B}, 1500 \mathrm{~nm}$; C, $2000 \mathrm{~nm}$.

In the $\mathrm{MCH}+$ neurons, $\mathrm{GABA}_{\mathrm{B}} \mathrm{R}$ immunostaining was prominent in the soma and appeared to be more dense following SC and SR than after SD (Fig. 5A-C). As for the Orx+ neurons, $\mathrm{GABA}_{B} \mathrm{R}$ immunostaining was nonetheless judged to be positive in all $\mathrm{MCH}+$ neurons (100\%) and in every group ( $n=4$ in SC and SR groups, $n=5$ in SD group; Fig. 1D2; Table 1). On the other hand, the luminance of $\mathrm{GABA}_{\mathrm{B}} \mathrm{R}$ immunostaining on the $\mathrm{MCH}+$ neurons was significantly lower after SD $(24.53 \pm 1.59, n$ $=50$ cells) compared with SC and SR (43.24 $\pm 2.87, n=$ 40 and $44.92 \pm 2.33, n=40$, respectively; Fig. 1E2; Table 1). The luminance did not differ between SC and $S R$, indicating that the $\mathrm{GABA}_{\mathrm{B}} \mathrm{R}$ returned to control or baseline levels during SR.

\section{Discussion}

The present results indicate that $\mathrm{GABA}_{\mathrm{A}}$ and $\mathrm{GABA}_{\mathrm{B}}$ receptors undergo dynamic and differential changes on Orx, wake-active and $\mathrm{MCH}$, sleep-active neurons as a function of SD and thus their homeostatic response to different activity changes.

\section{GABA $_{A}$ Rs differentially expressed as a function of sleep-wake activity}

$\mathrm{SD}$ during the day, when mice normally sleep the majority of the time, resulted in increased $G_{A B A} R$ labeling on the membrane of the Orx neurons presumably due to prolonged activity by the Orx neurons during enforced waking, as indicated by previous c-Fos and recording studies (Lee et al., 2005; Modirrousta et al., 2005). The Orx neurons show changes in $\mathrm{GABA}_{A} \mathrm{Rs}$ that are parallel to those for cholinergic basal forebrain neurons following SD, when those neurons are also active, as indicated by c-Fos expression (Modirrousta et al., 2007). In addition, in the whole hypothalamus, mRNA expression for $\mathrm{GABA}_{\mathrm{A}} \mathrm{R}(\beta$ subunits) is also increased after $\mathrm{SD}$ and high activity periods (Volgin et al., 2014). In contrast, however, SD resulted in decreased $G_{A B A} R$ labeling on the membrane 


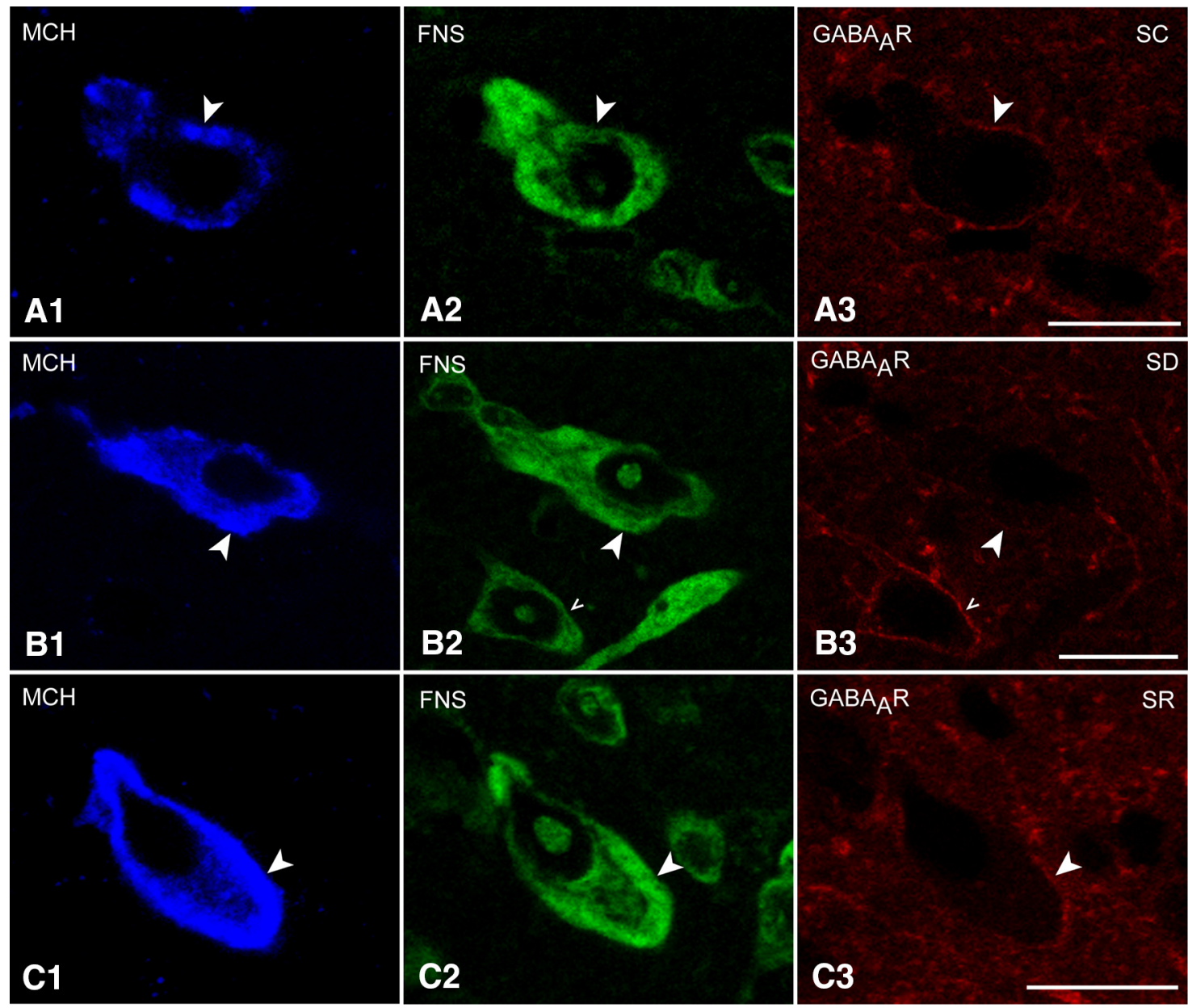

Figure 3. $G A B A_{A} R s$ in $M C H$ neurons across groups. Confocal images indicate that $G A B A_{A} R$ immunostaining (red) was moderate in $\mathrm{MCH}$ neurons (blue, indicated by filled arrowheads) though less than that in some adjacent $\mathrm{MCH}$-negative neurons (stained with FNS, green, indicated by carets). $\boldsymbol{A}, \mathrm{GABA}_{\mathrm{A}} \mathrm{R}$ immunostaining was present as clusters visible along the full plasma membrane of the cell body in an SC mouse. $\boldsymbol{B}, \mathrm{GABA}_{A} \mathrm{R}$ immunostaining was barely visible on $\mathrm{MCH}+$ neurons, whereas it was prominent on adjacent $\mathrm{MCH}$-negative neuron in an SD mouse. $C, \mathrm{GABA}_{\mathrm{A}} \mathrm{R}$ immunostaining appeared to be moderate in an SR mouse, similar to that in SC. Scale bars, $10 \mu \mathrm{m}$. Image thickness, $500 \mathrm{~nm}$.

of $\mathrm{MCH}$ neurons here, presumably due to silence of the $\mathrm{MCH}$ neurons during waking, as indicated in previous c-Fos and recording studies (Verret et al., 2003; Modirrousta et al., 2005; Hassani et al., 2009). The changes in $\mathrm{GABA}_{A} \mathrm{R}$ density on the membrane seen here in the Orx and $\mathrm{MCH}$ neurons are similar to those described in cultured hippocampal neurons following pharmacologically induced firing and silencing, respectively (Kilman et al., 2002; Marty et al., 2004). These changes in the density of $\mathrm{GABA}_{\mathrm{A}} \mathrm{R}$ clusters in the cultured neurons were moreover associated with increased versus decreased amplitude of miniature mIPSCs. An increase in membrane $\mathrm{GABA}_{\mathrm{A}} \mathrm{Rs}$ was also shown to occur in hippocampal neurons in vivo after increased activity induced by seizures and was associated with an increase in IPSCs (Nusser et al., 1998). This increase in postsynaptic receptors appears to be the most effective way by which the magnitude of inhibitory transmission is increased (Mody et al., 1994). Somewhat similar to ours, another study in mice showed that $\mathrm{GABA}_{\mathrm{A}} \mathrm{R}$ immunostaining (for the $\alpha 1$ subunit) was en- hanced and that the sensitivity to a $\mathrm{GABA}_{A} R$ agonist was increased along with the amplitude of IPSCs in Orx neurons following $6 \mathrm{~h}$ SD (Matsuki et al., 2015). The latter along with our results for the Orx neurons would appear to differ from those in rats showing increased amplitude of miniature EPSCs (mEPSCs) in Orx neurons following $4 \mathrm{~h}$ SD (Rao et al., 2007). However, the latter in vitro or ex vivo study was done in the presence of a $G_{A B A} R$ blocker (bicuculline) which did not allow assessment of changes in $\mathrm{GABA}_{A} \mathrm{R}$ currents and their potential influence on the mEPSCs. We can only assume that the increased activity by the Orx neurons during prolonged enforced waking stimulates homeostatic downscaling through increases in membrane $\mathrm{GABA}_{A} \mathrm{Rs}$, which would render the neurons more susceptible and responsive to inhibition by GABA. Reciprocally, the prolonged absence of activity by the $\mathrm{MCH}$ neurons during prolonged waking stimulates homeostatic upscaling through decreases in membrane $\mathrm{GABA}_{A} \mathrm{Rs}$, which would render them less susceptible and responsive to inhibition by $G A B A$. The $G A B A_{A}$ Rs returned 

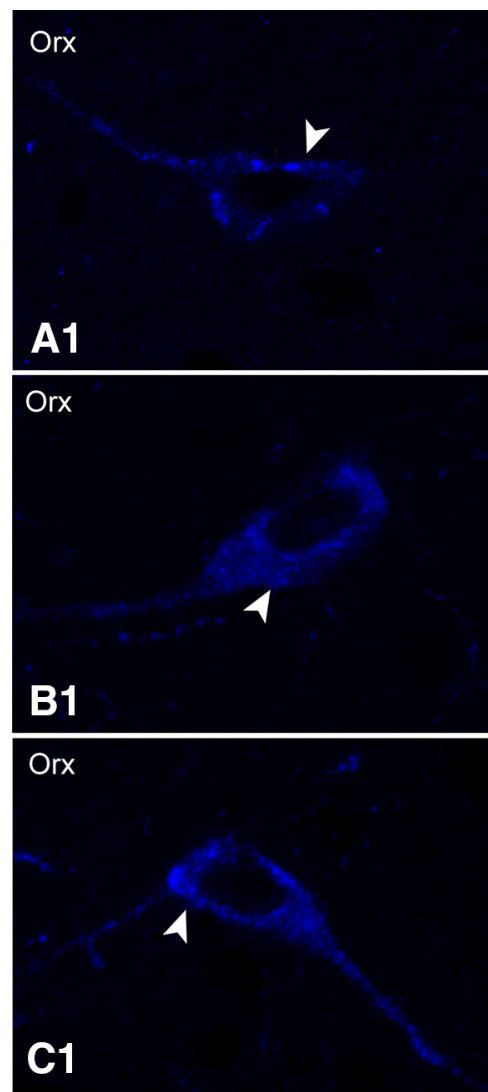
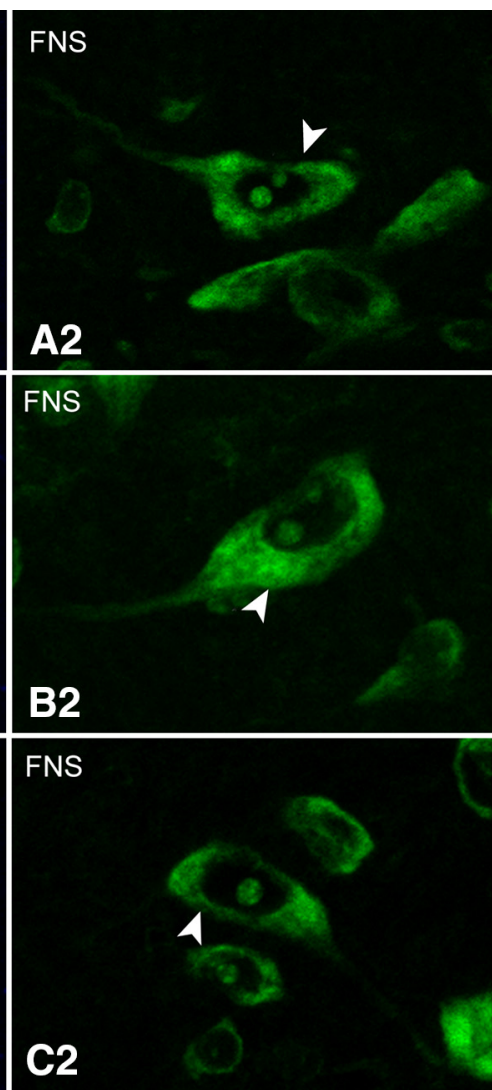

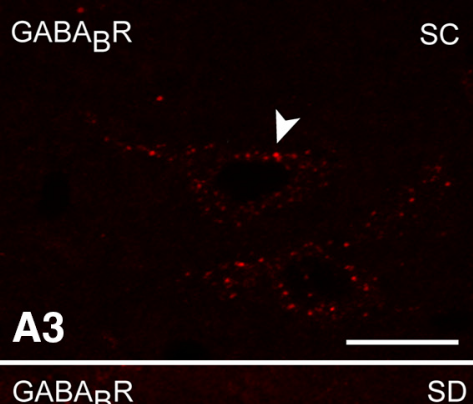

B3

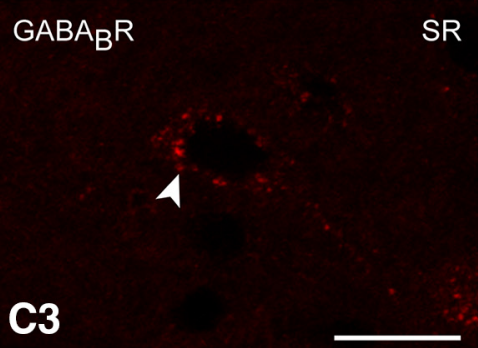

Figure 4. $G A B A_{B} R s$ in Orx neurons across groups. Confocal images of the $G A B A_{B} R$ immunostaining (red) in Orx neurons (blue, indicated by filled arrowheads). $\boldsymbol{A}$, The $\mathrm{GABA}_{B} \mathrm{R}$ immunofluorescence was minimally visible as clusters over the cytoplasm of an Orx + cell body in an SC mouse. $\boldsymbol{B}$, The GABA $\mathrm{B}_{\mathrm{B}} \mathrm{R}$ staining was more visible as larger clusters over the cytoplasm and partially on the plasma membrane of an Orx + cell in an SD mouse. $\boldsymbol{C}$, The GABA $\mathrm{B}$ staining was similar in an SR mouse to that in SC. Scale bars, $10 \mu \mathrm{m}$. Image thickness, $1500 \mathrm{~nm}$.

to baseline levels with SR, indicating a return to normal levels of excitability and activity in both Orx and $\mathrm{MCH}$ cells.

\section{GABA $_{B}$ Rs differentially expressed as a function of sleep-wake activity}

With regard to the metabotropic $\mathrm{GABA}_{\mathrm{B}} \mathrm{R}$ receptor, we found that all of the Orx and $\mathrm{MCH}$ neurons showed positive immunostaining for that receptor across all groups. On the other hand, the density of the $\mathrm{GABA}_{B} \mathrm{R}$ immunostaining appeared to differ according to cell type and group. By measurement of luminance, it was found that the intensity of $\mathrm{GABA}_{B}$ Rs in Orx neurons increased with $\mathrm{SD}$ presumably due to enhanced and prolonged activity with enforced waking, whereas that in $\mathrm{MCH}$ neurons decreased with SD, presumably due to prolonged silence. These results thus paralleled those of the $G A B A_{A} R$. In the case of the $G A B A_{B} R$, however, the immunostaining was most prominent in the cytoplasm and less evident on the plasma membrane. Although we did see staining along the membrane in some cases, we did not have adequate resolution for differentiation and systematic assessment of the membrane staining across groups. We can only assume that the different densities of $G A B A_{B}$ Rs with SD reflect different expression of the receptor in homeostatic response to different activities of the Orx and $\mathrm{MCH}$ neurons under the abnormal conditions of sustained waking during the day when mice normally sleep the majority of the time. As with the $\mathrm{GABA}_{A} \mathrm{Rs}$, the density of $\mathrm{GABA}_{\mathrm{B}} \mathrm{Rs}$ returned to $S C$ levels with $S R$, presumably reflecting the re-establishment of stable levels of excitability and activity during recovery sleep for both the Orx and $\mathrm{MCH}$ cells. Evidence from cultured hippocampus has indicated that the $\mathrm{GABA}_{B} \mathrm{R}$ is essential for homeostatic regulation of firing within hippocampal circuits through both presynaptic and postsynaptic mechanisms (Vertkin et al., 2015). Indeed, it has been known that genetic deletion of the $G_{A B A} R$ results in runaway excitation within these and cortical circuits resulting in seizure activity (Schuler et al., 2001), and that seizure activity is followed by increases in $\mathrm{GABA}_{\mathrm{B}} \mathrm{Rs}$ in hippocampal neurons (Straessle et al., 2003). Deletion of the $\mathrm{GABA}_{\mathrm{B}} \mathrm{R}$ also leads to disruption of the sleep-wake cycle in mice (Vienne et al., 2010). Fragmentation of the cycle also occurred in mice lacking $\mathrm{GABA}_{\mathrm{B}} \mathrm{Rs}$ specifically on Orx neurons (Matsuki et al., 2009).

\section{Role of GABA receptors in neuronal homeostasis and sleep-wake regulation}

GABA receptors, particularly $\mathrm{GABA}_{A} \mathrm{Rs}$, have been shown to play an important role in the homeostatic regulation of 


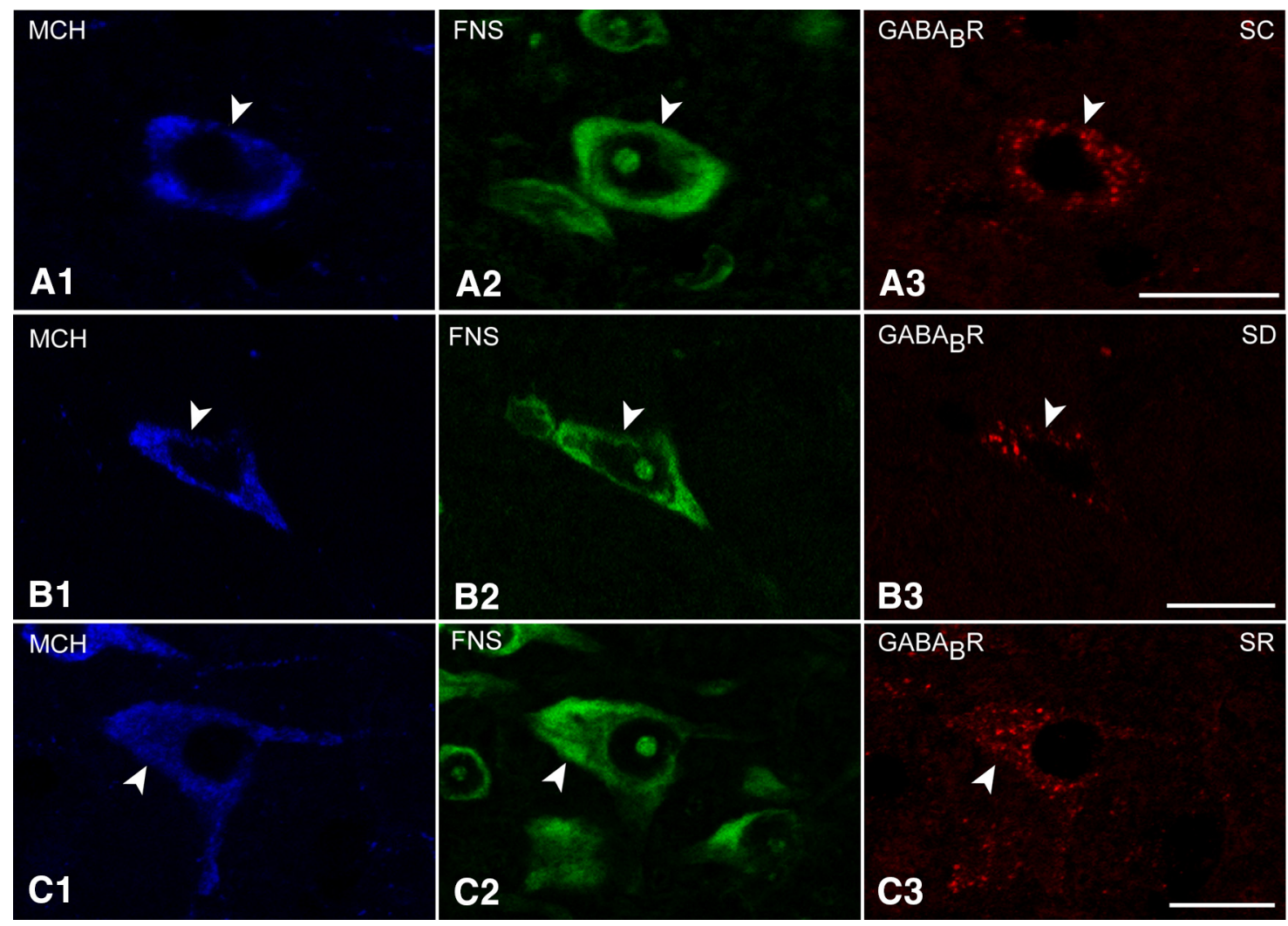

Figure 5. $\mathrm{GABA}_{B} \mathrm{Rs}$ in $\mathrm{MCH}$ neurons across groups. Confocal images of the $\mathrm{GABA}_{\mathrm{B}} \mathrm{R}$ immunostaining (red) in $\mathrm{MCH}$ neurons (blue, indicated by filled arrowheads). $A, G A B A_{B} R$ immunostaining was present as prominent large clusters over the cytoplasm of an $\mathrm{MCH}+$ neuron in an SC mouse. $\boldsymbol{B}$, The $\mathrm{GABA}_{\mathrm{B}} \mathrm{R}$ immunostaining was minimally visible over the cytoplasm of an $\mathrm{MCH}+$ neuron in an $\mathrm{SD}$ mouse. $\boldsymbol{C}$, The $\mathrm{GABA}_{B} \mathrm{R}$ immunostaining appeared to be prominent over the cytoplasm and near the plasma membrane of an SR mouse, similar to that in SC. Scale bars, $10 \mu \mathrm{m}$. Image thickness: $\boldsymbol{A}, 2000 \mathrm{~nm} ; \boldsymbol{B}, \boldsymbol{C}, 1500 \mathrm{~nm}$.

neuronal excitability as a function of activity (Turrigiano, 1999). Here, we present evidence that dynamic and differential changes in both $\mathrm{GABA}_{A}$ and $\mathrm{GABA}_{B}$ receptors after SD reflect homeostatic downscaling following prolonged activity by the wake-active, Orx neurons and upscaling following inactivity by the sleep-active, $\mathrm{MCH}$ neurons.

Both $\mathrm{GABA}_{A}$ and $\mathrm{GABA}_{B}$ receptors, along with GABA, are known to play an important role in sleep. Most hypnotic drugs act upon the benzodiazepine binding site of the $\mathrm{GABA}_{A} \mathrm{R}$ to enhance GABA-mediated currents (Wafford and Ebert, 2008; Winsky-Sommerer, 2009; Feren et al., 2011). Some, like anesthetic agents (eg, barbiturates), act directly upon the $\mathrm{GABA}_{A} \mathrm{R}$ ion channel (Franks, 2008). Interestingly, anesthesia with $G_{A B A_{A}} R$ agonists (eg, propofol) can actually serve in the homeostatic response to SD in place of natural sleep recovery (Tung and Mendelson, 2004). Reciprocally, SD lowers the threshold to anesthesia induction, likely due to homeostatic changes in the $\mathrm{GABA}_{A} \mathrm{R}$. Gamma hydroxybutyrate (GHB) used in the treatment of narcolepsy with cataplexy acts upon the $G A B A_{B} R$ to consolidate sleep with low muscle tone during sleeping periods, such as to reduce narcoleptic attacks during the following waking period in humans and rodents (Xie et al., 2006; Vienne et al., 2010; Boscolo-Berto et al., 2012; Black et al., 2014). Moreover,
GHB or its metabolite can alleviate the behavioral and physiological effects of sleep deprivation (Walsh et al., 2010). These results would also suggest that pharmacological effects upon the $G A B A_{B} R$, as upon the $G A B A_{A} R$, can mimic the homeostatic effects of sleep. However, such pharmacological effects are rarely cell specific and thus can affect both wake- and sleep-active cell groups, which as we show here would normally undergo differential homeostatic changes in their GABA receptors depending upon their state selective activity.

Sleep is regulated in a homeostatic manner (Borbély and Achermann, 1999), whereby SD is compensated for by enhanced NREM or slow wave sleep and delta EEG activity along with increased REM sleep. Whereas Orx neurons normally promote waking and prevent sleep including importantly REM sleep with muscle atonia (Mieda et al., 2004; Adamanitidis et al., 2007; Tsunematsu et al., 2011) $\mathrm{MCH}$ neurons normally enhance sleep including importantly REM sleep with muscle atonia (Verret et al., 2003; Jego et al., 2013; Konadhode et al., 2013; Tsunematsu et al., 2014). The reciprocal changes in the inhibitory GABA receptors and presumed excitability and activity of the Orx and $\mathrm{MCH}$ neurons seen here with SD could thus underlie the homeostatic response of decreased arousal and increased sleepiness during depri- 
vation and increased sleep, including REM sleep, during recovery.

We conclude that expression and density of both $G_{A B A}$ and $G A B A_{B}$ receptors increase on Orx neurons because of prolonged activity and reciprocally decrease on $\mathrm{MCH}$ neurons because of prolonged inactivity during SD. These reciprocal changes in excitability of the Orx and $\mathrm{MCH}$ neurons could decrease arousal and increase sleepiness along with sleep pressure during SD. During $\mathrm{SR}$, the GABA receptors return to baseline presumably returning the excitability and activity of the Orx and $\mathrm{MCH}$ neurons to stable levels and thus restoring normal arousal while removing sleep pressure.

\section{References}

Adamantidis AR, Zhang F, Aravanis AM, Deisseroth K, de Lecea L (2007) Neural substrates of awakening probed with optogenetic control of hypocretin neurons. Nature 450:420-424. CrossRef Medline

Bittencourt JC, Presse F, Arias C, Peto C, Vaughan J, Nahon JL, Vale W, Sawchenko PE (1992) The melanin-concentrating hormone system of the rat brain: an immuno- and hybridization histochemical characterization. J Comp Neur 319:218-245. CrossRef Medline

Black SW, Morairty SR, Chen TM, Leung AK, Wisor JP, Yamanaka A, Kilduff TS (2014) GABAB agonism promotes sleep and reduces cataplexy in murine narcolepsy. J Neurosci 34:6485-6494. CrossRef Medline

Bonino M, Cantino D, Sassoè-Pognetto M (1999) Cellular and subcellular localization of gamma-aminobutyric acidB receptors in the rat olfactory bulb. Neurosci Lett 274:195-198. Medline

Borbély AA, Achermann P (1999) Sleep homeostasis and models of sleep regulation. J Biol Rhythms 14:557-568. Medline

Boscolo-Berto R, Viel G, Montagnese S, Raduazzo DI, Ferrara SD, Dauvilliers $Y$ (2012) Narcolepsy and effectiveness of gammahydroxybutyrate (GHB): a systematic review and meta-analysis of randomized controlled trials. Sleep Med Rev 16:431-443. CrossRef Medline

Broberger C, De Lecea L, Sutcliffe JG, Hökfelt T (1998) Hypocretin/ orexin- and melanin-concentrating hormone-expressing cells form distinct populations in the rodent lateral hypothalamus: relationship to the neuropeptide $Y$ and agouti gene-related protein systems. J Comp Neur 402:460-474. Medline

Chemelli RM, Willie JT, Sinton CM, Elmquist JK, Scammell T, Lee C, Richardson JA, Williams SC, Xiong Y, Kisanuki Y, Fitch TE, Nakazato M, Hammer RE, Saper CB, Yanagisawa M (1999) Narcolepsy in orexin knockout mice: molecular genetics of sleep regulation. Cell 98:437-451. Medline

de Lecea L, Kilduff TS, Peyron C, Gao X, Foye PE, Danielson PE, Fukuhara C, Battenberg EL, Gautvik VT, Bartlett FS 2nd, Frankel WN, van den Pol AN, Bloom FE, Gautvik KM, Sutcliffe JG (1998) The hypocretins: hypothalamus-specific peptides with neuroexcitatory activity. Proc Natl Acad Sci U S A 95:322-327. CrossRef

Eggermann E, Bayer L, Serafin M, Saint-Mleux B, Bernheim L, Machard D, Jones BE, Muhlethaler M (2003) The wake-promoting hypocretin-orexin neurons are in an intrinsic state of membrane depolarization. J Neurosci 23:1557-1562.

Feren S, Schweitzer PK, Walsh JK (2011) Pharmacotherapy for insomnia. Handb Clin Neurol 99:747-762. CrossRef Medline

Filippov AK, Couve A, Pangalos MN, Walsh FS, Brown DA, Moss SJ (2000) Heteromeric assembly of $\mathrm{GABA}_{B} \mathrm{R} 1$ and $\mathrm{GABA}_{\mathrm{B}} \mathrm{R} 2$ receptor subunits inhibits $\mathrm{Ca}^{2+}$ current in sympathetic neurons. J Neurosci 20:2867-2874. Medline

Franks NP (2008) General anaesthesia: from molecular targets to neuronal pathways of sleep and arousal. Nat Rev Neurosci 9:370386. CrossRef Medline
Fritschy JM, Mohler H (1995) GABA $_{A}$-receptor heterogeneity in the adult rat brain: differential regional and cellular distribution of seven major subunits. J Comp Neur 359:154-194. CrossRef Medline

Hassani OK, Lee MG, Jones BE (2009) Melanin-concentrating hormone neurons discharge in a reciprocal manner to orexin neurons across the sleep-wake cycle. Proc Natl Acad Sci U S A 106:24182422. CrossRef Medline

Jego S, Glasgow SD, Herrera CG, Ekstrand M, Reed SJ, Boyce R, Friedman J, Burdakov D, Adamantidis AR (2013) Optogenetic identification of a rapid eye movement sleep modulatory circuit in the hypothalamus. Nat Neurosci 16:1637-1643. CrossRef Medline

Kilman V, van Rossum MC, Turrigiano GG (2002) Activity deprivation reduces miniature IPSC amplitude by decreasing the number of postsynaptic $\mathrm{GABA}_{\mathrm{A}}$ receptors clustered at neocortical synapses. J Neurosci 22:1328-1337. Medline

Konadhode RR, Pelluru D, Blanco-Centurion C, Zayachkiversusky A, Liu M, Uhde T, Glen WB Jr, van den Pol AN, Mulholland PJ, Shiromani PJ (2013) Optogenetic stimulation of $\mathrm{MCH}$ neurons increases sleep. J Neurosci 33:10257-10263. CrossRef Medline

Lee MG, Hassani OK, Jones BE (2005) Discharge of identified orexin/ hypocretin neurons across the sleep-waking cycle. J Neurosci 25:6716-6720. CrossRef Medline

Margeta-Mitrovic M, Mitrovic I, Riley RC, Jan LY, Basbaum Al (1999) Immunohistochemical localization of $\mathrm{GABA}_{\mathrm{B}}$ receptors in the rat central nervous system. J Comp Neur 405:299-321. Medline

Marty S, Wehrlé R, Fritschy JM, Sotelo C (2004) Quantitative effects produced by modifications of neuronal activity on the size of $\mathrm{GABA}_{\mathrm{A}}$ receptor clusters in hippocampal slice cultures. Eur J Neurosci 20:427-440. CrossRef Medline

Matsuki T, Takasu M, Hirose Y, Murakoshi N, Sinton CM, Motoike T, Yanagisawa M (2015) GABAA receptor-mediated input change on orexin neurons following sleep deprivation in mice. Neuroscience 284:217-224. CrossRef Medline

Matsuki T, Nomiyama M, Takahira H, Hirashima N, Kunita S, Takahashi S, Yagami K, Kilduff TS, Bettler B, Yanagisawa M, Sakurai T (2009) Selective loss of $\mathrm{GABA}_{B}$ receptors in orexin-producing neurons results in disrupted sleep/wakefulness architecture. Proc Natl Acad Sci U S A 106:4459-4464. CrossRef Medline

Mieda M, Willie JT, Hara J, Sinton CM, Sakurai T, Yanagisawa M (2004) Orexin peptides prevent cataplexy and improve wakefulness in an orexin neuron-ablated model of narcolepsy in mice. Proc Natl Acad Sci U S A 101:4649-4654. CrossRef Medline

Modirrousta M, Mainville L, Jones BE (2005) Orexin and MCH neurons express c-Fos differently after sleep deprivation versus recovery and bear different adrenergic receptors. Eur J Neurosci 21:2807-2816. CrossRef Medline

Modirrousta M, Mainville L, Jones BE (2007) Dynamic changes in GABAA receptors on basal forebrain cholinergic neurons following sleep deprivation and recovery. BMC Neurosci 8:15. CrossRef Medline

Mody I, De Koninck Y, Otis TS, Soltesz I (1994) Bridging the cleft at GABA synapses in the brain. Trends Neurosci 17:517-525. Medline

Nusser Z, Hájos N, Somogyi P, Mody I (1998) Increased number of synaptic $\mathrm{GABA}_{\mathrm{A}}$ receptors underlies potentiation at hippocampal inhibitory synapses. Nature 395:172-177. CrossRef Medline

Peyron C, et al. (2000) A mutation in a case of early onset narcolepsy and a generalized absence of hypocretin peptides in human narcoleptic brains. Nat Med 6:991-997. CrossRef

Rao Y, Liu ZW, Borok E, Rabenstein RL, Shanabrough M, Lu M, Picciotto MR, Horvath TL, Gao XB (2007) Prolonged wakefulness induces experience-dependent synaptic plasticity in mouse hypocretin/orexin neurons. J Clin Invest 117:4022-4033. CrossRef Medline

Schuler V, Lüscher C, Blanchet C, Klix N, Sansig G, Klebs K, Schmutz M, Heid J, Gentry C, Urban L, Fox A, Spooren W, Jaton AL, Vigouret J, Pozza M, Kelly PH, Mosbacher J, Froestl W, Käslin E, Korn R, et al. (2001) Epilepsy, hyperalgesia, impaired memory, 
and loss of pre- and postsynaptic $\mathrm{GABA}_{B}$ responses in mice lacking $\mathrm{GABA}_{\mathrm{B}(1)}$. Neuron 31:47-58. Medline

Straessle A, Loup F, Arabadzisz D, Ohning GV, Fritschy JM (2003) Rapid and long-term alterations of hippocampal GABAB receptors in a mouse model of temporal lobe epilepsy. Eur $\mathrm{J}$ Neurosci 18:2213-2226. Medline

Thannickal TC, Moore RY, Nienhuis R, Ramanathan L, Gulyani S, Aldrich M, Cornford M, Siegel JM (2000) Reduced number of hypocretin neurons in human narcolepsy. Neuron 27:469-474. Medline

Tsunematsu T, Kilduff TS, Boyden ES, Takahashi S, Tominaga M, Yamanaka A (2011) Acute optogenetic silencing of orexin/hypocretin neurons induces slow-wave sleep in mice. J Neurosci 31: 10529-10539. Medline

Tsunematsu T, Ueno T, Tabuchi S, Inutsuka A, Tanaka KF, Hasuwa H, Kilduff TS, Terao A, Yamanaka A (2014) Optogenetic manipulation of activity and temporally controlled cell-specific ablation reveal a role for $\mathrm{MCH}$ neurons in sleep/wake regulation. J Neurosci 34:6896-6909. Medline

Tung A, Mendelson WB (2004) Anesthesia and sleep. Sleep Med Rev 8:213-225. CrossRef Medline

Turrigiano GG (1999) Homeostatic plasticity in neuronal networks: the more things change, the more they stay the same. Trends Neurosci 22:221-227. Medline

Turrigiano GG, Leslie KR, Desai NS, Rutherford LC, Nelson SB (1998) Activity-dependent scaling of quantal amplitude in neocortical neurons. Nature 391:892-896. CrossRef Medline

van den Pol AN, Acuna-Goycolea C, Clark KR, Ghosh PK (2004) Physiological properties of hypothalamic $\mathrm{MCH}$ neurons identified with selective expression of reporter gene after recombinant virus infection. Neuron 42:635-652. Medline

Verret L, Goutagny R, Fort P, Cagnon L, Salvert D, Leger L, Boissard R, Salin P, Peyron C, Luppi PH (2003) A role of melanin- concentrating hormone producing neurons in the central regulation of paradoxical sleep. BMC Neurosci 4:19. CrossRef

Vertkin I, Styr B, Slomowitz E, Ofir N, Shapira I, Berner D, Fedorova T, Laviv T, Barak-Broner N, Greitzer-Antes D, Gassmann M, Bettler B, Lotan I, Slutsky I (2015) GABAB receptor deficiency causes failure of neuronal homeostasis in hippocampal networks. Proc Natl Acad Sci U S A 112:E3291-3299. CrossRef Medline

Vienne J, Bettler B, Franken P, Tafti M (2010) Differential effects of GABAB receptor subtypes, \{gamma\}-hydroxybutyric Acid, and Baclofen on EEG activity and sleep regulation. J Neurosci 30: 14194-14204. CrossRef Medline

Volgin DV, Lu JW, Stettner GM, Mann GL, Ross RJ, Morrison AR, Kubin L (2014) Time- and behavioral state-dependent changes in posterior hypothalamic GABAA receptors contribute to the regulation of sleep. PLoS One 9:e86545. CrossRef Medline

Wafford KA, Ebert B (2008) Emerging anti-insomnia drugs: tackling sleeplessness and the quality of wake time. Nat Rev Drug Discov 7:530-540. CrossRef Medline

Walsh JK, Hall-Porter JM, Griffin KS, Dodson ER, Forst EH, Curry DT, Eisenstein RD, Schweitzer PK (2010) Enhancing slow wave sleep with sodium oxybate reduces the behavioral and physiological impact of sleep loss. Sleep 33:1217-1225. Medline

Wan Q, Xiong ZG, Man HY, Ackerley CA, Braunton J, Lu WY, Becker LE, MacDonald JF, Wang YT (1997) Recruitment of functional $\mathrm{GABA}_{\mathrm{A}}$ receptors to postsynaptic domains by insulin. Nature 388 : 686-690. CrossRef Medline

Winsky-Sommerer R (2009) Role of GABAA receptors in the physiology and pharmacology of sleep. Eur J Neurosci 29:1779-1794. CrossRef Medline

Xie X, Crowder TL, Yamanaka A, Morairty SR, Lewinter RD, Sakurai $T$, Kilduff TS (2006) GABA $_{B}$ receptor-mediated modulation of hypocretin/orexin neurones in mouse hypothalamus. J Physiol 574:399-414. CrossRef Medline 